\section{Relationship between social capital indicators and lifestyle in Brazilian adults}

\author{
Asociación entre indicadores de capital social y \\ estilo de vida en adultos brasileños
}

Associação entre indicadores de capital social e
estilo de vida em adultos brasileiros
Mathias Roberto Loch 1 Regina Kazue Tanno de Souza ${ }^{2}$ Arthur Eumann Mesas 2 David Martinez-Gómez ${ }^{3}$ Fernando Rodríguez-Artalejo ${ }^{3}$

\footnotetext{
1 Departamento de Educação Física, Universidade Estadual de Londrina, Londrina Brasil.

2 Programa de Pós-graduação em Saúde Coletiva

Universidade Estadual de Londrina, Londrina, Brasil. 3 Departamento de Medicina Preventiva y Salud Pública, Universidad Autónoma de Madrid, Madrid, España.

Correspondence M. R. Loch Departamento de Educação Física, Universidade Estadual de Londrina Rod. Celso Garcia Cid, Km 380, Campus Universitário Londrina, $P R$ 86051-990, Brasil mathias@uel.br
}

\begin{abstract}
The present study examined the relationship between indicators of social capital and healthrelated behaviors. A cross-sectional study was conducted on a sample of 1,062 participants representative of the population aged 40 years or older from a city in Southern Brazil. The following indicators of social capital were examined: number of friends, number of people they could borrow money from when in need; extent of trust in community members; number of times members of the community help each other; community safety; and extent of membership in community activities. Also, an overall score of social capital including all indicators was calculated. A poor social capital was associated with insufficient leisure-time physical activity $(O R=1.70$; 95\%CI: 1.07-2.70), low consumption of fruits and vegetables $(O R=1.53 ; 95 \% C I: 1.05-2.24)$, and smoking $(O R=1.97 ; 95 \% C I$ : 1.21-3.21). No clear association was found between capital social and binge drinking. A score of social capital showed an inverse relationship with the number of prevalent risk behaviors $(p<0.001)$. These results reinforce that policies to promote health should consider social capital.
\end{abstract}

Social Capital; Life Style; Social Participation; Adult

\section{Resumen}

El objetivo del estudio fue investigar la relación entre indicadores de capital social y los comportamientos relacionados con la salud. Se realizó un estudio transversal con 1.062 personas representativas de la población de 40 años o más, de una ciudad del Sur del Brasil. Los indicadores de capital social fueron: número de amigos y personas que prestan dinero si fuera necesario, la confianza en la gente del barrio, la frecuencia con la que la gente del barrio se ayuda mutuamente, la seguridad del barrio y la participación comunitaria. También se construyó una puntuación del capital social en base a indicadores aislados de capital social. Un bajo capital social se asoció con la inactividad física en el tiempo libre $(O R=$ 1,70; IC95\%: 1,07-2,70), el consumo irregular de frutas y verduras $(O R=1,53$; IC95\%: 1,5-2,24), y el tabaquismo (OR = 1,97; IC95\%: 1,21-3,21). No hubo una clara relación entre el capital social y el abuso de alcohol. La puntuación del capital social ha tenido una relación inversa con el número de conductas de riesgo $(p<0,001)$. Estos resultados refuerzan la importancia de considerar el capital social en las políticas de promoción de la salud.

Capital Social; Estilo de Vida; Participación Social; Adulto 


\section{Introduction}

Mortality and chronic noncommunicable disease rates are strongly associated with behavioral factors $1,2,3$. Individual and social determinants of lifestyle have been extensively researched in recent years, however some of these determinants need to be further explored and more evidence produced to support health promotion interventions 4 .

It has recently been suggested that social capital is a health determinant $5,6,7,8$. Social capital has been defined in a number of different ways with subtle differences 9,10,11,12,13,14. For the sake of comparison with previous epidemiological research, we considered that social capital is defined as features of social organization that involve mutual trust, norms of reciprocity, and social networks that enable people to act collectively, thereby more effectively pursuing a common purpose 5,8,12. Furthermore, social capital has been classified into four categories: structural (related to civic and political aspects); cognitive (perceptions and expectations about social behavior and community sense); formal (structured and/or legal organizations and/or processes); and informal (spontaneous interaction with members of the community, relatives, peers, and/or friends).

According to the report of the National Commission on Social Determinants of Health in Brazil 15, the social capital consists of social and community networks and involves all the relations of solidarity and trust between individuals and groups. A low social capital results from social and economic inequities, and has shown a negative impact on the health status of communities with weaker social bonds; these communities have a low investment in human capital and social support networks, and less participation of the population in the definition of public policies. There is evidence that individuals with greater social capital tend to be more physically active $16,17,18,19,20,21$, have better eating habits 22,23 and lower frequency of smoking $24,25,26,27,28,29$. However, the relationship between social capital and alcohol consumption is still uncertain; while the lack of institutional trust is associated with harmful alcohol intake 30 , high social participation has also been linked to increased alcohol consumption 26 .

Moreover, the mechanisms of the relationship between social capital and health behaviors are not fully understood. Kawachi \& Berkman 5 suggest three hypotheses: social capital promotes more rapid dissemination of information, increases the likelihood that healthy behaviors are adopted as standards, and exerts social control over unhealthy behaviors.
The relationship between social capital and various health indicators may vary according to local characteristics, including levels of violence, economic and social development and democratic tradition. Although most studies point to a positive relationship between social capital and self-perceived health, a study found that electoral participation and membership in community forums were inversely associated with self-perceived health in rural areas of Colombia 31 .

In this context, the general aim of this study was to improve understanding of the relationship between social capital indicators and lifestyle. Specifically this study tested the hypothesis that among individuals from a representative sample of the adult population in a mid-size city in Southern Brazil, those who perceive a better social capital in the community show healthier behaviors. This hypothesis is based on the assumption that better social organization, greater perceived support networks and greater security in the community, among other factors, can facilitate the adoption of behaviors considered positive for health. This study is relevant because it may produce evidence on lifestyle determinants and thus provide input for the development of sound policies to promote healthy behaviors.

\section{Methods}

\section{Study population}

The study participants were drawn from residents of the city of Cambé, Paraná State, Brazil, aged 40 years or older included in a larger cross-sectional study named VIGICARDIO (Cardiovascular Diseases in Paraná State-mortality, risk profile, drug therapy and complications). This age cutoff was chosen due to the higher prevalence of cardiovascular disease and their risk factors from age 40 and onwards 32 . Located in the South Region of Brazil, Cambé has a population of 96,735 inhabitants and a human development index of 0.793 33. Households were randomly selected from all census tracts, and people aged $\geq 40$ years were identified and invited to participate in the study. The study sample was selected in age- and sex-strata from the distribution of census tracts in the urban area, where households were chosen randomly. All 86 urban census tracts in the city were included in the study. The sample size was calculated using Epi Info 3.5.1 software (Centers for Disease Control and Prevention, Atlanta, USA), considering an expected $50 \%$ prevalence of unhealthy behaviors and a $95 \%$ confidence interval (95\%CI) of three percentage points; it resulted in a sample of 1,062 subjects. Based on the as- 
sumption of up to $25 \%$ non-identification plus non-response, the final sample size was 1,339.

Only one resident per household was interviewed and interviews continued until the quota for gender-age categories was reached. When two or more residents in the same household met the inclusion criteria, the respondent was selected at random. Data was collected by trained interviewers during home visits from January to July 2011. Additional information about the selection and composition of the study sample is available in Souza et al. 34

Of a total of 1,339 eligible respondents, 1,180 (88.1\%) participated in the study. Among the 159 non-participants, 93 refused to participate and 66 were not located after three or more visits on different days and at different times. For the analysis of this study, we excluded respondents who did not answer one or more questions about indicators of social capital $(n=76)$, potential confounders $(n=38)$, and risk behaviors $(n=4)$. The final sample comprised 1,062 respondents.

The study was approved by the Ethics Research Committee at the Londrina State University.

\section{Study variables}

The survey instrument included information on many health and social domains, but in this study we used data only for social capital indicators (independent variables), health behaviors (dependent variables) and some socio-demographic variables (potential confounders).

\section{- Health-related behaviors}

The studied health-related behaviors were physical activity in leisure time, consumption of fruits and vegetables, smoking, and binge drinking. These behaviors were selected because they are well established cardiovascular risk factors and are part of the Brazilian Ministry of Health's National Policy of Health Promotion 35 which includes, among other priority objectives, the promotion of healthy eating and physical activity, and the prevention of tobacco use and binge drinking.

Information on physical activity leisure-time was obtained with the following question: "During a typical week, in your leisure time, what types of physical activities do you often engage in?". Study participants were also asked about the frequency (per day/week) and duration (minutes/ day) of each activity. Walking, stretching, dancing, water aerobics, biking, and localized exercise training were considered activities of moderate intensity, while weight training, fitness training, and sports were considered vigorous activities. This information was used to establish whether individuals met the current recommendations: at least 150 minutes of moderate-to-vigorous physical activity, or 60 minutes of vigorous physical activity per week 36,37 .

Information on consumption of fruits and vegetables, smoking, and alcohol use was collected using the Risk and Protective Factors Surveillance System for Chronic Non-Comunicable Diseases Through Telephone Interview (VIGITEL) questionnaire, a computer-assisted telephone survey instrument used by the Brazilian Ministry of Health in the Federal District and Brazilian state capitals 38 .

Irregular consumption of fruits and/or vegetables was an indicator of unhealthy food behavior. It was assessed using two questions: "How many days of the week do you usually eat a fruit serving?" and "How many days of the week do you usually eat at least a serving of vegetables or legumes (e.g., lettuce, tomato, collard greens, chayote, eggplant, and zucchini), excluding potatoes, cassava or yam?". Those who responded $<5$ days/week in any of the two questions were classified as irregular consumers of fruits and vegetables. Although this frequency is lower than that generally considered in dietary guidelines, it was used in a large telephone-based study conducted by the Brazilian Ministry of Health and, thus, it is adequate to place the present results within the context of this country.

Smoking was assessed with the following question: "Do you smoke?". Smokers were those who reported current smoking regardless of their smoking history and number of packs smoked per day.

Binge drinking was identified when the participant answered positively to the following question: "During the last 30 days, did you have four or more (for women)/five or more (for men) drinks containing any kind of alcohol on a single occasion?". A drink was defined as a can of beer, a glass of wine or a shot of cachaça, whisky or any other distilled alcoholic beverage.

\section{- Social capital indicators}

The following six indicators of social capital were examined: number of friends, number of people they could borrow money from when in need; extent of trust in community members; number of times members of the community help each other; community safety; and extent of membership in community or civic activities. The questions were drawn from the Brazilian version of the Integrated Questionnaire for the Measurement of Social Capital (QI-MSC) 39, and social capital 
indicators were selected from previous studies $17,18,20,21,40$. The selected indicators included various categories of social capital: cognitive (trust in community members, frequency of help and community safety), structural (participation in community activities), formal (also, participation in community activities) and informal (number of friends and number of people to borrow money from). Importantly, the indicators used are not sufficient to evaluate, in its entirety, the social capital construct.

\section{- Confounding variables}

Information was collected on potential confounders, e.g., sociodemographic factors and health conditions associated with health-related behaviors and with social capital. Specifically, data were obtained on the following variables: gender, age (40-49; 50-59; 60 years and more); education (none to four; five to eight; and nine years or more of schooling); socioeconomic condition (based on the Brazilian Criterion of Economic Classification ${ }^{41}$ and categorized as A and $\mathrm{B}$ [high]; and C, D, and E [low]); body mass index (BMI) (normal weight $\left[<25 \mathrm{~kg} / \mathrm{m}^{2}\right.$ ], overweight $\left[25-29.9 \mathrm{~kg} / \mathrm{m}^{2}\right]$, and obese $\left[\geq 30 \mathrm{~kg} / \mathrm{m}^{2}\right]$ ); reported mobility limitation; reported chronic medical condition diagnosed by a doctor or other health professional (hypertension, diabetes, high cholesterol, angina, congestive heart failure, acute myocardial infarction, cerebrovascular disease, chronic renal failure or chronic lung disease); and self-perceived health (very good/good; fair/ poor/very poor).

All data were obtained through a pretested questionnaire, except for BMI that was calculated from height and weight measurements taken with standard techniques.

\section{Statistical analysis}

The association between indicators of social capital and health-related behaviors was assessed by the odds ratio (OR) and its 95\%CI obtained from logistic regression after adjusting for potential confounders.

Additionally, an overall score of social capital was calculated based on the responses obtained for each indicator. Thus, a score of 2 was given to those reporting four or more friends, 1 to those reporting one to three friends, and 0 for no friends. For the remaining indicators, a score of 1 was given for those who reported at least one person from whom they could borrow money in case of need, trust in community members, that members of the community always or almost always helped each other, that their community was safe and that had been involved in community activities in the past 12 months. An overall score of social capital ranging from 0 to 7 was obtained by summing up individual scores of each indicator. Respondents were then categorized into three groups: higher social capital (6-7); intermediate social capital (4-5); and lower-poor social capital (0-4). Continuous scores were used to assess the dose-response relationship between the social capital score and risk behaviors, and a p-value for linear trend was estimated. Although this score was created as a simple way to summarize the main study associations, its psychometric properties were not analyzed; thus, it cannot be interpreted as a validated social capital assessment tool.

Statistical significance for the relationship between the social capital indicators and healthrelated behaviors was set at two-sided $\mathrm{p}<0.05$, while for the interaction of the social capital score with demographic and health variables it was set at $\mathrm{p}<0.10$. The analyses were performed using IBM SPSS version 19.0 (IBM Corp., Armonk, USA).

\section{Results}

In the study population, the largest group of individuals was of female gender, aged between 40 and 59, classified as medium or low economic level, had less than nine years of schooling, overweight or obese, did not present any functional limitation, reported at least one chronic disease and reported to be in good or very good health.

In total, $81.8 \%$ of the study participants did not meet the recommended levels of physical activity (83.4\% of women; $79.9 \%$ of men), $62.9 \%$ showed irregular consumption of fruits and/or vegetables ( $52.3 \%$ of women and $75.9 \%$ of men), $20 \%$ were current smokers $(15.2 \%$ of women and $25 \%$ of men), and $18 \%$ binge drinkers ( $7 \%$ of women and $30.9 \%$ of men). Sociodemographic and health status variables associated with these health-related behaviors are shown in Tables 1 (women) and Table 2 (men).

We found that a greater proportion of men than women had four or more friends and considered the community to have a low level of violence. The distribution of other social capital indicators showed no gender difference. As regards socioeconomic status, all indicators of social capital were better in people with higher status, except frequency of help which presented no difference (data not shown).

An association was found between insufficient leisure-time physical activity and some indicators of social capital (number of friends, 
Prevalence of health-related behaviors according to demographic and clinical variables among women $(n=574)$. Cambé, Paraná State, Brazil, 2011

\begin{tabular}{|c|c|c|c|c|c|}
\hline & Total & $\begin{array}{c}\text { Insufficient } \\
\text { leisure-time } \\
\text { physical activity }\end{array}$ & $\begin{array}{l}\text { Irregular } \\
\text { consumption } \\
\text { of fruits and/or } \\
\text { vegetables }\end{array}$ & Smoking & Binge drinking \\
\hline & $\mathbf{n}$ & $\%$ & $\%$ & $\%$ & $\%$ \\
\hline Total & 574 & 83.4 & 52.3 & 15.2 & 7.0 \\
\hline \multicolumn{6}{|l|}{ Age group (years) } \\
\hline $40-49$ & 233 & 85.0 & 55.8 & 23.6 & 13.7 \\
\hline $50-59$ & 181 & 81.8 & 51.1 & 11.0 & 4.4 \\
\hline 60 or more & 160 & 83.1 & 48.4 & 7.5 & 0.0 \\
\hline \multicolumn{6}{|l|}{ Socioeconomic condition } \\
\hline A-B (high) & 195 & 77.9 & 39.8 & 14.3 & 6.6 \\
\hline C-D-E (low) & 379 & 86.3 & 58.7 & 15.6 & 7.1 \\
\hline \multicolumn{6}{|l|}{ Education (years of schooling) } \\
\hline 9 or more & 162 & 78.4 & 44.8 & 14.1 & 10.4 \\
\hline $5-8$ & 127 & 85.8 & 50.8 & 21.4 & 12.7 \\
\hline$<5$ & 285 & 85.3 & 57.2 & 13.0 & 2.5 \\
\hline \multicolumn{6}{|l|}{ Body mass index } \\
\hline Normal $\left(<25 \mathrm{~kg} / \mathrm{m}^{2}\right)$ & 152 & 81.6 & 51.0 & 22.2 & 8.5 \\
\hline Overweight $\left(25-29.9 \mathrm{~kg} / \mathrm{m}^{2}\right)$ & 206 & 81.6 & 51.0 & 13.1 & 8.3 \\
\hline Obese $\left(\geq 30 \mathrm{~kg} / \mathrm{m}^{2}\right)$ & 216 & 86.6 & 54.4 & 12.1 & 4.7 \\
\hline \multicolumn{6}{|l|}{ Mobility limitation } \\
\hline No & 530 & 82.5 & 50.9 & 15.1 & 7.0 \\
\hline Yes & 44 & 95.5 & 68.2 & 15.9 & 6.8 \\
\hline \multicolumn{6}{|l|}{ Reported chronic disease } \\
\hline No & 210 & 81.0 & 52.1 & 19.0 & 9.0 \\
\hline Yes & 364 & 84.9 & 52.3 & 12.9 & 5.8 \\
\hline \multicolumn{6}{|l|}{ Self-perceived health } \\
\hline Very good/Good & 294 & 75.9 & 47.8 & 14.7 & 9.2 \\
\hline Fair/Poor/Very poor & 280 & 91.4 & 59.6 & 15.7 & 4.6 \\
\hline
\end{tabular}

frequency of help, participation in community activities. Also we observed an inverse doseresponse relationship $(\mathrm{p}<0.001)$ between the social capital score and physical inactivity $(\mathrm{p}<0.001)$ (Table 3$)$.

Irregular consumption of fruits and/or vegetables was associated with non-participation in community activities and with a lower social capital score $(p=0.017)$. Smoking was linked to the frequency with which members of the community help each other and with the social capital score $(p=0.014)$. In addition, the adjusted mean score of social capital was calculated for those who were never-, former- and currentsmokers. A significantly lower mean score was found among current smokers compared to the other two categories (data not shown). Of all risk behaviors examined, binge drinking was the variable that was least associated with indicators of social capital. Only the frequency of help was associated with alcohol use.

A regression analysis was performed to assess whether gender, age, socioeconomic condition, and education might modify the relationship between indicators of social capital and risk behaviors. No interaction effects were seen $(p>0.10)$, except for binge drinking and age $(\mathrm{p}=0.036)$; the association between a lower score of social capital and higher frequency of binge drinking was only observed among younger participants (4049 years old).

Finally, the higher the social capital score the lower the mean number of risk behaviors. Respondents with the highest score showed 1.51 
Prevalence of health-related behaviors according to demographic and clinical variables among men $(n=488)$. Cambé, Paraná State, Brazil, 2011

\begin{tabular}{|c|c|c|c|c|c|}
\hline & Total & $\begin{array}{c}\text { Insufficient } \\
\text { leisure-time } \\
\text { physical activity }\end{array}$ & $\begin{array}{c}\text { Irregular } \\
\text { consumption } \\
\text { of fruits and/or } \\
\text { vegetables }\end{array}$ & Smoking & Binge drinking \\
\hline & $\mathbf{n}$ & $\%$ & $\%$ & $\%$ & $\%$ \\
\hline Total & 488 & 79.9 & 75.9 & 25.0 & 30.9 \\
\hline \multicolumn{6}{|l|}{ Age group (years) } \\
\hline $40-49$ & 203 & 82.3 & 82.3 & 21.7 & 34.5 \\
\hline $50-59$ & 157 & 79.6 & 75.8 & 30.6 & 37.9 \\
\hline 60 or more & 128 & 76.6 & 64.8 & 23.4 & 17.2 \\
\hline \multicolumn{6}{|l|}{ Socioeconomic condition } \\
\hline A-B (high) & 213 & 77.9 & 69.0 & 15.0 & 30.5 \\
\hline C-D-E (low) & 275 & 81.5 & 80.7 & 32.7 & 31.3 \\
\hline \multicolumn{6}{|l|}{ Education (years of schooling) } \\
\hline 9 or more & 131 & 71.0 & 65.6 & 11.5 & 32.1 \\
\hline $5-8$ & 138 & 79.7 & 81.3 & 30.9 & 36.7 \\
\hline$<5$ & 219 & 85.4 & 78.0 & 29.4 & 26.6 \\
\hline \multicolumn{6}{|l|}{ Body mass index } \\
\hline Normal $\left(<25 \mathrm{~kg} / \mathrm{m}^{2}\right)$ & 176 & 79.0 & 79.0 & 37.5 & 36.9 \\
\hline Overweight $\left(25-29.9 \mathrm{~kg} / \mathrm{m}^{2}\right)$ & 203 & 78.8 & 74.9 & 16.3 & 28.1 \\
\hline Obese $\left(\geq 30 \mathrm{~kg} / \mathrm{m}^{2}\right)$ & 109 & 83.5 & 71.6 & 21.1 & 26.6 \\
\hline \multicolumn{6}{|l|}{ Mobility limitation } \\
\hline No & 473 & 79.5 & 75.4 & 24.6 & 32.0 \\
\hline Yes & 15 & 93.3 & 81.3 & 37.5 & 0.0 \\
\hline \multicolumn{6}{|l|}{ Reported chronic disease } \\
\hline No & 229 & 79.5 & 76.9 & 24.5 & 36.2 \\
\hline Yes & 259 & 80.3 & 74.5 & 25.5 & 26.3 \\
\hline \multicolumn{6}{|l|}{ Self-perceived health } \\
\hline Very good/Good & 320 & 76.6 & 70.9 & 22.5 & 29.7 \\
\hline Fair/Poor/Very poor & 168 & 86.3 & 84.5 & 29.8 & 33.3 \\
\hline
\end{tabular}

risk behaviors, while those with the lowest scores had 2.10 behaviors (adjusted data) (Figure 1).

The results were rather similar after stratification by gender, though stronger associations were seen between social capital and smoking in men, and between social capital and irregular consumption of fruits and vegetables in women (data not shown).

\section{Discussion}

This cross-sectional population-based study aimed to examine the association between indicators of social capital and health-related behaviors. Overall, lower scores of social capital were associated with greater likelihood of insufficient leisure-time physical activity, irregular consumption of fruits and/or vegetables, and smoking. The higher the score of social capital, the lower the mean number of prevalent risk behaviors.

Overall, the prevalence of the risk behaviors examined in this study was similar to that reported in other Brazilian studies, and the same was true for the differences found by demographic and health-related variables $42,43,44,45,46,47$.

Although it is not yet fully understood how social capital may favor health-related behaviors, it is believed that they can promote information dissemination and increase social control over risk behaviors 5. Furthermore, health-related behaviors can mediate the association between social capital and relevant health indicators, including self-rated health 40,48 . 
Association between indicators of social capital and risk behaviors (OR and 95\%Cl), Cambé, Paraná State, Brazil, 2011. $(\mathrm{N}=1,062)$.

\begin{tabular}{|c|c|c|c|c|}
\hline & $\begin{array}{c}\text { Insufficient } \\
\text { leisure-time } \\
\text { physical activity }\end{array}$ & $\begin{array}{l}\text { Irregular } \\
\text { consumption } \\
\text { of fruits and/or } \\
\text { vegetables }\end{array}$ & Smoking & Binge drinking \\
\hline & OR $(95 \% \mathrm{Cl})$ & OR $(95 \% \mathrm{Cl})$ & OR $(95 \% \mathrm{Cl})$ & OR $(95 \% \mathrm{Cl})$ \\
\hline \multicolumn{5}{|l|}{ Number of friends } \\
\hline 4 or more & 1.00 & 1.00 & 1.00 & 1.00 \\
\hline $1-3$ & $1.11(0.78-1.58)$ & $1.26(0.94-1.69)$ & $1.31(0.92-1.86)$ & $0.85(0.58-1.25)$ \\
\hline None & $2.45(1.26-4.77)$ & $1.18(0.76-1.83)$ & $1.41(0.87-2.30)$ & $0.94(0.55-1.62)$ \\
\hline $\mathrm{p}$-value for linear trend & 0.031 & 0.209 & 0.089 & 0.600 \\
\hline \multicolumn{5}{|c|}{ Number of people to borrow } \\
\hline \multicolumn{5}{|l|}{ money from } \\
\hline One or more & 1.00 & 1.00 & 1.00 & 1.00 \\
\hline None & $1.03(0.71-1.50)$ & $1.24(0.91-1.68)$ & $1.27(0.89-1.80)$ & $1.04(0.70-1.54)$ \\
\hline \multicolumn{5}{|c|}{ Trust in community members } \\
\hline Yes & 1.0 & 1.0 & 1.00 & 1.00 \\
\hline No & $1.17(0.84-1.62)$ & $1.22(0.93-1.61)$ & $1.11(0.80-1.55)$ & $0.93(0.66-1.32)$ \\
\hline \multicolumn{5}{|l|}{ Frequency of help } \\
\hline Always/Almost always & 1.00 & 1.00 & 1.00 & 1.00 \\
\hline Sometimes/Rarely & $1.46(1.06-2.02)$ & $1.15(0.88-1.50)$ & $1.71(1.23-2.38)$ & $1.62(1.14-2.31)$ \\
\hline \multicolumn{5}{|l|}{ Community safety } \\
\hline Low level of violence & 1.00 & 1.00 & 1.00 & 1.00 \\
\hline $\begin{array}{l}\text { Medium/High level of } \\
\text { violence }\end{array}$ & $1.31(0.90-1.91)$ & $1.23(0.92-1.65)$ & $1.23(0.88-1.73)$ & $1.16(0.79-1.70)$ \\
\hline \multicolumn{5}{|l|}{ Participation in community } \\
\hline Yes & 1.00 & 1.00 & 1.00 & 1.00 \\
\hline No & $1.47(1.05-2.06)$ & $1.43(1.08-1.88)$ & $1.27(0.91-1.77)$ & $1.14(0.79-1.63)$ \\
\hline \multicolumn{5}{|l|}{ Social capital score } \\
\hline 6-7 (higher) & 1.00 & 1.00 & 1.00 & 1.00 \\
\hline $4-5$ & $1.13(0.76-1.67)$ & $0.98(0.69-1.38)$ & $1.88(1.18-3.00)$ & $1.06(0.68-1.65)$ \\
\hline 0-4 (lower) & $1.70(1.07-2.70)$ & $1.53(1.05-2.24)$ & $1.97(1.21-3.21)$ & $1.30(0.81-2.10)$ \\
\hline$p$-value for linear trend & 0.002 & 0.017 & 0.014 & 0.257 \\
\hline
\end{tabular}

95\% Cl: 95\% confidence interval - adjusted for gender, age group, socioeconomic condition, education, body mass index, mobility limitation, reported chronic condition, and self-perceived health; OR: odds ratio.

Frequency of help and participation in community activities were inversely associated with several unhealthy behaviors. In contrast, having a person to borrow money from when in need and trust in community members were more weakly associated with these behaviors. This is relevant because the relationship between indicators of social capital and lifestyle may vary with the context. In Japan perceptions and expectations of social behavior and community sense are more linked to the cognitive aspect of social capital and have shown to be more strongly associated with physical activity 18 , while in the
United States this same association was more evident with structural indicators of social capital (political and civic participation) 49. In our study both structural and cognitive aspects were similarly associated with physical inactivity, but they showed different associations with the rest of behaviors. The number of times members of the community help each other was also associated with smoking and binge drinking, whereas participation in community activities was associated with irregular consumption of fruits and/ or vegetables. 
Mean number of risk behaviors by social capital score (0-7) including the following behaviors: physical inactivity, irregular consumption of fruits and vegetables, binge drinking and smoking adjusted for confounders $(N=1,062)$. Cambé, Paraná State, Brazil, 2011.

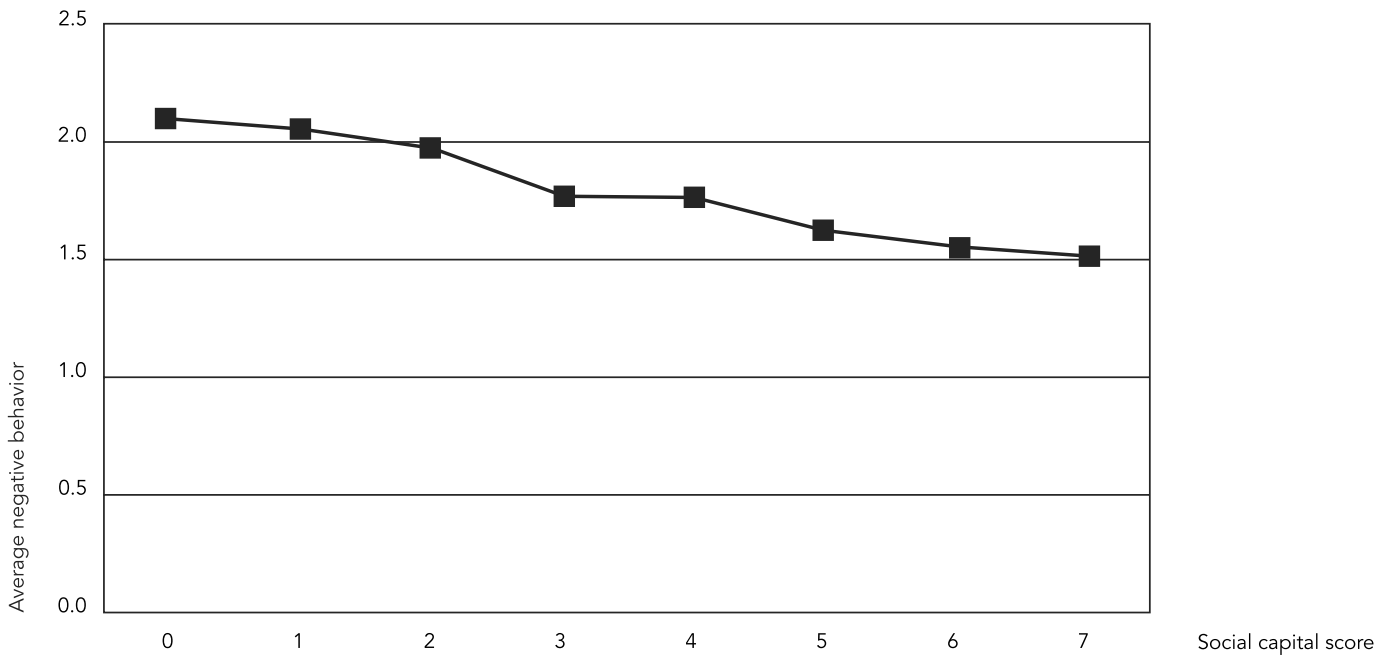

Of all risk behaviors examined, physical inactivity was the most associated with indicators of social capital. There was a great difference in the prevalence of physical inactivity between those with four or more friends and those with no friends. This finding is consistent with the literature since lower social support has been identified as a major barrier to leisure-time physical activity 50 . However, we chose to examine only physical activity at leisure time because public policies in Brazil focus on this dimension, given that household and work-related activity and the transportation to the workplace are more related to individual's needs than to the desire of achieving good health.

Community safety, which has been considered a major factor for promoting physical activity 51 , was only associated with leisure-time physical inactivity. Violence can have disruptive effects that create an atmosphere of social conflict and a culture of fear affecting community regulations that govern solidarity practices and relations 12 .

Irregular consumption of fruits and/or vegetables was only associated with participation in community activities and the score of social capital. This may be partly explained by the existence of community-owned orchards run by local residents. By growing their own fruit and vegetables, they increase people's access to natural products and encourage an active involvement in community activities and interpersonal trust. Further studies should assess the impact of these community initiatives on social capital and food consumption.

Smoking showed an inverse association with frequency of help and the social capital score. A study conducted in Chile found an inverse relationship between trust in community members and the prevalence of smoking, but it did not find smoking to be associated with trust in organizations, reciprocal relationships with community members, community integration, and social participation 29 . The present study showed a higher social capital score among those who never smoked and former smokers compared to current smokers, suggesting that social capital may favor both smoking prevention and cessation. However, this needs to be interpreted with caution because current social capital may differ from social capital at the time the respondents quit smoking. A study with Finnish workers found that smokers who had higher social capital were more likely to quit smoking 52 .

Of note was that binge drinking was not associated with poorer social capital; it may be due to the fact that people tend to consume larger amounts of alcohol when socializing. Although alcohol intake is more frequent in younger adults 
as a way of experimentation and socializing 53 , it is also possible that those aged $\geq 40$ years follow a similar pattern, i.e. drink more alcohol when socializing. Furthermore, the relationship between social capital and excessive alcohol weakened with age. We have no clear explanation for this finding, which should be replicated in future research.

Although there is no consensus on the best approach to assess social capital, we used the same indicators as in previous studies. Also, an overall score of social capital was constructed. The inverse dose-response relationship between the social capital score and the frequency of the studied risk behaviors suggests that there is a sort of synergistic effect of these social capital indicators.

The strengths of this study included a high response rate and the use of a representative sample from a city in a developing Latin American country where there are few studies on the relationship between indicators of social capital and health behaviors 7 . Several indicators of social capital were included so that major dimensions of this construct were assessed, and our analysis examined a number of risk behaviors. A limitation of this study is its cross-sectional design, which did not allow for causal inference. Some of these behaviors, such as physical activity, can be causally related to higher social capital; on the other hand, a Danish study developed a physi- cal activity intervention to improve indicators of social capital in a local community and found a greater impact of team sports (soccer) than individual physical activities (running) 54 . Thus, the direction of the associations between social capital and health behaviors requires further exploration in prospective studies. In addition, future research should assess if these associations vary with age. Finally, an additional limitation is that results of this study may not apply to individuals below the age of 40 .

In conclusion, there is a moderate association between different indicators of socal capital and health-related behaviors, evidencing a clear relationship with physical inactivity and a less strong association with irregular consumption of fruits and/or vegetables and smoking. Our results suggest that the degree and local characteristics of social capital should be considered in the development of health promotion policies. For example, the development, implementation and evaluation of health promotion interventions should have a higher participation and empowerment of the community, which agrees with the health promotion principles. Moreover, further research should have a longitudinal design and qualitative approaches to better understand how social capital can affect behaviors, and include interventions to promote social capital and evaluate its impact on lifestyle. 


\section{Resumo}

O objetivo do estudo foi verificar a associação entre indicadores de capital social e comportamentos relacionados à saúde. Foi realizado um estudo transversal com uma amostra de 1.062 sujeitos representativos da população de 40 anos ou mais de um município da Região Sul do Brasil. Os indicadores de capital social foram: número de amigos, pessoas que emprestariam dinheiro em caso de necessidade, confiança nas pessoas do bairro, frequência com que as pessoas no bairro se ajudavam, segurança no bairro e participação comunitária. Foi ainda calculado um escore de capital social que considerou os indicadores isolados. Baixo capital social foi associado com inatividade física no lazer $(O R=1,70$; IC95\%: 1,07-2,70), consumo irregular de frutas e verduras $(O R=1,53$; IC95\%: 1,05-2,24) e tabagismo (OR = 1,97; IC95\%: 1,21-3,21). Não foi encontrada associação clara do capital social com o consumo abusivo de álcool. O escore de capital social mostrou uma relação inversa com o número de comportamentos de risco $(p<0,001)$. Esses resultados reforçam a importância de se considerar o capital social nas políticas de promoção da saúde.

Capital Social; Estilo de Vida; Participação Social; Adulto

\section{Contributors}

M. R. Loch, R. K. T. Souza and A. E. Mesas participated in all stages of the study and revision of the article. D. Martinez-Gómez participated in the data analysis and revision of the article. F. Rodríguez-Artalejo was responsible for providing guidance for the entire article.

\section{Acknowledgments}

We wish to acknowledge the support of Capes for providing a study grant from the Institutional Programme for Sandwich Doctorates Abroad (process number 724212-3).

\section{References}

1. Kvaavik E, Batty GD, Ursin G, Huxley R. Gale CR Influence of individual and combined health behaviors on total and cause-specific mortality in men and women: the United Kingdom health and lifestyle survey. Arch Intern Med 2010; 170:711-8.

2. Odegaard AO, Koh WP, Gross MD, Yuan JM, Pereira MA. Combined lifestyle factors and cardiovascular disease mortality in Chinese men and women: the Singapore Chinese health study. Circulation 2011; 124:2847-54.

3. Shaw BA, Agahi N. A prospective cohort study of health behavior profiles after age 50 and mortality risk. BMC Public Health 2012; 12:803.
4. Bauman AE, Reis RS, Sallis JF, Wells JC, Loos RJ. Martin BW. Correlates of physical activity: why are some people physically active and others not? Lancet 2012; 380:258-71.

5. Kawachi I, Berkman L. Social cohesion, social capital and health. In: Berkman L, Kawachi I, editors. Social epidemiology. Oxford: Oxford University Press; 2000. p. 174-90.

6. Kim D, Subramanian SV, Kawachi I. Social capital and physical health: a systematic review of literature. In: Kawachi I, Subramania SV, Kim D, editors. Social capital and health. New York: Springer; 2008. p. 139-90. 
7. Kripper CE, Sapag JC. Capital social y salud en América Latina y el Caribe: una revisión sistemática. Rev Panam Salud Pública 2009; 25:162-70.

8. Pattussi MP, Moysés SJ, Junges JR. Sheiham A. Capital social e a agenda da epidemiologia. Cad Saúde Pública 2006; 22:1525-46.

9. Barata RB, Almeida Filho N. Barreto ML. Epidemiologia social. In: Almeida Filho N, Barreto ML, editores. Epidemiologia e saúde: fundamentos, métodos, aplicações. Rio de Janeiro: Editora Guanabara Koogan; 2011. p. 375-85.

10. Bordieu P. Capital social - notas provisórias. In: Nogueira MA, Catani A, editores. Escritos de Educação. Petrópolis: Editora Vozes; 1999. p. 65-9.

11. D’Araújo MD. Capital social. Rio de Janeiro: Jorge Zahar Editores; 2003.

12. Matos H. Capital social e comunicação: interfaces e articulações. São Paulo: Summus Editorial; 2009.

13. Portes A. Capital social: origens e aplicações na sociologia contemporânea. Sociologia, Problemas e Práticas 2000; 33:133-58.

14. Putnam R. Comunidade e democracia: a experiência da Itália moderna. Rio de Janeiro: Editora FGV; 1998.

15. Comissão Nacional sobre Determinantes Sociais da Saúde. As causas sociais das iniquidades em saúde no Brasil: relatório final da comissão nacional sobre determinantes sociais da saúde; 2008. http://bvsms.saude.gov.br/bvs/publicacoes/cau sas_sociais_iniquidades.pdf (accessed on 12/Dec/ 2014).

16. Lindstrom M, Moghaddassi M, Merlo J. Social capital and leisure time physical activity: a population based multilevel analysis in Malmo, Sweden. J Epidemiol Community Health 2003; 57:23-8.

17. Mummery WK, Lauder W, Schofield G, Caperchione C. Associations between physical inactivity and a measure of social capital in a sample of Queensland adults. J Sci Med Sport 2008; 11:308-15.

18. Ueshima K, Fujiwara T, Takao S, Suzuki E, Iwase T, Doi H, et al. Does social capital promote physical activity? A population-based study in Japan. PLoS One 2010; 5:e12135.

19. Ball K, Cleland VJ, Timperio AF, Salmon J, GilesCorti B, Crawford DA. Love thy neighbour? associations of social capital and crime with physical activity amongst women. Soc Sci Med 2010; 71:80714.

20. Legh-Jones H, Moore S. Network social capital, social participation, and physical inactivity in an urban adult population. Soc Sci Med 2012; 74: 1362-7.

21. Lindstrom M. Social capital, desire to increase physical activity and leisure-time physical activity: a population-based study. Public Health 2011; 125:442-7.

22. Ball K, Jeffery RW, Abbott G, McNaughton SA, Crawford D. Is healthy behavior contagious: associations of social norms with physical activity and healthy eating. Int J Behav Nutr Phys Act 2010; 7:86.
23. Johnson CM, Sharkey JR, Dean WR. Eating behaviors and social capital are associated with fruit and vegetable intake among rural adults. J Hunger Environ Nutr 2010; 5:302-15.

24. Lindström M, Moghaddassi M, Bolin K, Lindgren B, Merlo J. Social participation, social capital and daily tobacco smoking: a population-based multilevel analysis in Malmo, Sweden. Scand J Public Health 2003; 31:444-50.

25. Lindström M, Janzon E. Social capital, institutional (vertical) trust and smoking: a study of daily smoking and smoking cessation among ever smokers. Scand J Public Health 2007; 35:460-7.

26. Chuang YC, Chuang KY. Gender differences in relationships between social capital and individual smoking and drinking behavior in Taiwan. Soc Sci Med 2008; 67:1321-30.

27. Lindstrom M. Social capital, social class and tobacco smoking. Expert Rev Pharmacoecon Outcomes Res 2008; 8:81-9.

28. Afifi RA, Nakkash RT, Khawaja M. Social capital, women's autonomy and smoking among married women in low-income urban neighborhoods of Beirut, Lebanon. Womens Health Issues 2010; 20:156-67.

29. Sapag JC, Poblete FC, Eicher C, Aracena M, Caneo C, Vera G, et al. Tobacco smoking in urban neighborhoods: exploring social capital as a protective factor in Santiago, Chile. Nicotine Tob Res 2010; 12:927-36.

30. Ahnquist J, Lindstrom M, Wamala SP. Institutional trust and alcohol consumption in Sweden: the Swedish National Public Health Survey 2006. BMC Public Health 2008; 8:283.

31. Hurtado D, Kawachi I. Sudarsky J. Social capital and self-rated health in Colombia: the good, the bad and the ugly. Soc Sci Med 2011; 72:584-90.

32. Schmidt MI, Duncan BB, Azevedo e Silva G, Menezes AM, Monteiro CA, Barreto SM, et al. Chronic non-communicable diseases in Brazil: burden and current challenges. Lancet 2011; 377:1949-61.

33. Instituto Brasileiro de Geografia e Estatística. Censo demográfico 2010. Rio de Janeiro: Instituto Brasileiro de Geografia e Estatística; 2010.

34. Souza RKT, Bortoletto MSS, Loch MR, González AD, Matsuo T, Cabrera MAS, et al. Prevalência de fatores de risco cardiovascular em pessoas com 40 anos ou mais de idade, em Cambé, Paraná (2011): estudo de base populacional. Epidemiol Serv Saúde 2013; 22:435-44.

35. Departamento de Vigilância de Doenças e Agravos não Transmissíveis e Promoção da Saúde, Secretaria de Vigilância em Saúde, Ministério da Saúde. Minuta da Portaria de revisão da Política Nacional de Promoção da Saúde. http://www.blog.saude. gov.br/index.php/570-destaques/34641-ministe rio-lanca-politica-nacional-de-promocao-da-sau de (accessed on 12/Dec/2014).

36. Haskell WL, Lee IM, Pate RR, Powell KE, Blair SN, Franklin BA, et al. Physical activity and public health: updated recommendation for adults from the American College of Sports Medicine and the American Heart Association. Circulation 2007; 116:1081-93. 
37. World Health Organization. Global recommendantions on physical activity for health. Geneva: World Health Organization; 2010.

38. Secretaria de Vigilância em Saúde, Ministério da Saúde. VIGITEL 2010. Vigilância de fatores de risco e proteção para doenças crônicas por inquérito telefônico. Brasília: Ministério da Saúde; 2011.

39. Grootaert C, Narayan D, Nylan V. Wookcook JM. Questionário integrado para medir capital social - versão brasileira; 2003. http://empreende.org. br/pdf/Capital\%20Social\%20e\%20Cidadania/ Question\%C3\%A1rio\%20Integrado\%20para\%20 Medir\%20Capital\%20Social.pdf (accessed on 07/ Jul/2014)

40. Mohnen SM, Volker B, Flap H, Groenewegen PP Health-related behavior as a mechanism behind the relationship between neighborhood social capital and individual health: a multilevel analysis. BMC Public Health 2012; 12:116.

41. Associação Brasileira de Empresas de Pesquisas. Critério de classificação econômica. São Paulo: Associação Brasileira de Empresas de Pesquisas; 2008.

42. Hallal PC, Knuth AG, Reis RS, Rombaldi AJ, Malta DC, Iser BP, et al. Tendências temporais de atividade física no Brasil (2006-2009). Rev Bras Epidemiol 2011; 14 Suppl 1:S53-60.

43. Jaime PC, Figueiredo IC, Moura EC. Malta DC. Fatores associados ao consumo de frutas e hortaliças no Brasil, 2006. Rev Saúde Pública 2009; 43 Suppl 2:57-64.

44. Knuth AG, Malta DC, Dumith SC, Pereira CA, Morais Neto OL, Temporão JG, et al. Prática de atividade física e sedentarismo em brasileiros: resultados da Pesquisa Nacional por Amostra de Domicílios (PNAD) 2008. Ciênc Saúde Coletiva 2011; 16:3697-705.

45. Laranjeira R, Pinsky I, Sanches M, Zaleski M. Caetano R. Alcohol use patterns among Brazilian adults. Rev Bras Psiquiatr 2010; 32:231-41.
46. Moura EC, Silva SA, Malta DC, Morais Neto OL. Fatores de risco e proteção para doenças crônicas: vigilância por meio de inquérito telefônico, VIGITEL, Brasil, 2007. Cad Saúde Pública 2011; 27: 486-96.

47. Reisdorfer E, Buchele F, Pires RO, Boing AF. Prevalence and associated factors with alcohol use disorders among adults: a population-based study in southern Brazil. Rev Bras Epidemiol 2012; 15: 582-94.

48. Poortinga W. Do health behaviors mediate the association between social capital and health? Prev Med 2006; 43:488-93.

49. Greiner KA, Li C, Kawachi I, Hunt DC. Ahluwalia JS. The relationships of social participation and community ratings to health and health behaviors in areas with high and low population density. Soc Sci Med 2004; 59:2303-12.

50. Silva IC, Azevedo MR. Goncalves H. Leisure-time physical activity and social support among Brazilian adults. J Phys Act Health 2013; 10:871-9.

51. Bennett GG, McNeill LH, Wolin KY, Duncan DT, Puleo E, Emmons KM. Safe to walk? Neighborhood safety and physical activity among public housing residents. PLoS Med 2007; 4:1599-606.

52. Kouvonen A, Oksanen T, Vahtera J, Vaananen A, De Vogli R, Elovainio M, et al. Work-place social capital and smoking cessation: the Finnish Public Sector Study. Addiction 2008; 103:1857-65.

53. Koutra K, Kritsotakis G, Orfanos P, Ratsika N, Kokkevi A, Philatithis A. Social capital and regular alcohol use and binge drinking in adolescence: a cross-sectional study in Greece. Drugs: Education, Prevention, and Policy 2014; 21:299-309.

54. Ottesen L, Jeppesen RS, Krustrup BR. The development of social capital through football and running: studying an intervention program for inactive women. Scand J Med Sci Sports 2010; 20 Suppl 1:118-31.

Submitted on 01/Sep/2014

Final version resubmitted on 16/Dec/2014

Approved on 02/Mar/2015 